\title{
The Piltdown angel
}

\author{
Dig for victory.
}

\section{John P. Boyd}

Our archaeological team had found the skeleton of a small, six-winged hominid in an aluminium casket buried under an Irish peat bog. But I didn't suspect Andrei until one night when he pointed at Mars.

"The colonists will envy our Angel." He laughed. "If they can't dig up his brother, they'll make one!" He sighed. "Will the World Space Agency really abandon Mars, Adelard?"

I shrugged. The Climate War is turning us inward. Bangladesh is underwater. Florida's an archipelago. Waves of refugees are moving, all over the globe. Every country feels like Hitler in the Bunker. Lost souls, just trying to survive. "Maybe in 50 years there'll be time for dreams, Andrei — and Mars."

I couldn't sleep. Andrei's smirk, so like Dad's dogsbody...

My father had once been a Harvard dean. He named me after the scholar Adelard of Bath, who had travelled to Antioch to consult original sources around 1115. But Dad was too trusting. He kept churning out books as dean, a mere proofreader of tomes ghost-written by his assistants. One lowly postdoc, suffering from both depression and anxiety disorder, scribbled stories half-remembered from undergraduate classes instead of consulting the archives. My father was only suspended without pay for a year, losing his deanship and chair.

I would not be destroyed like Dad! Sir Keith gave me a way to fight back a few hours after we pried open the casket. He said: "This is now a crime scene. We've found something big. But radical discoveries are accepted only with the strongest, most indisputable evidence. The dig protocols must be followed to the letter as if each was a test by a malevolent deity on which your life depends. Because this is a test. We'll be strongly criticized, examined and probed, looking for the slightest weakness. Jealousy is a chronic scholarly virus!"

Andrei hated the fussiness. "Like a Soviet submarine!" he grumbled. "No man can move a pebble without another beside him, like his political commissar."

Sarah Frane was a very good commissar. Unlike Andrei, a soil geologist, she was soft science, and believed in history the way a medieval nun believed in Mary.

When the heavy rains came, her allergies worsened. I teased her.

"Did you ever think, Sarah, that our

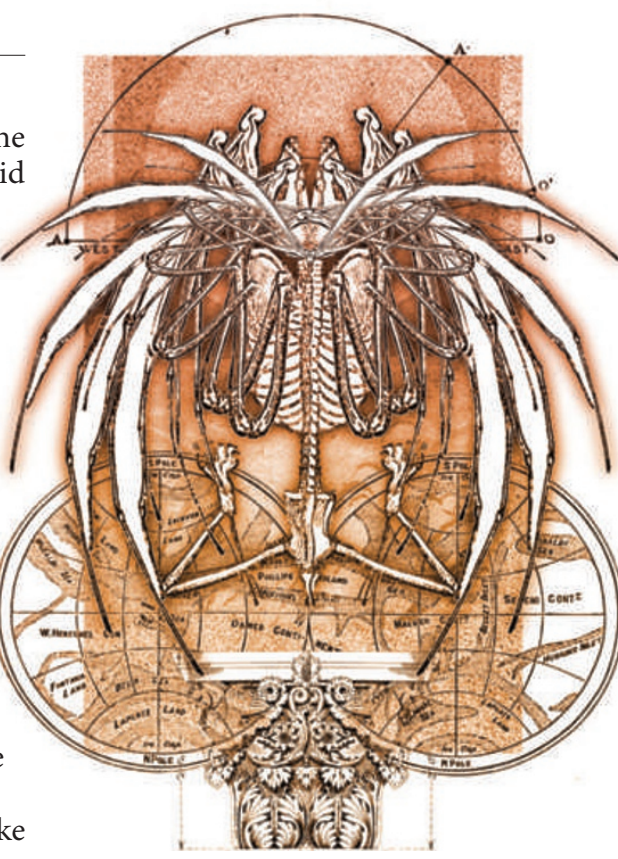

Angel might be another Piltdown Man?" She scowled.

"An early hominid excavated in East Sussex in 1912. Orang-utan jaw mated with a modern skull, age-stained with iron and chromic acid."

She shook her head. "I'm busy!"

An hour later, I added: "The teeth were filed for consistency with the prejudice that big brains evolved before an omnivorous diet." I blocked her view of the soil-sifter. "By 1915, Boule and Miller independently wrote that the jaw was an ape's."

She counterattacked. "You're our palaeontologist. You've touched the bones. X-ray, CT scan, chemical analysis."

A riposte! "They're not bird or pterodactyl wings," I admitted. “They're real bones, like nothing else on Earth."

Still, she was worried, and I attacked after lunch. "Why would aliens hide from us, and then foolishly bury one of their own where it might be dug up?"

She looked like she was going to cry. A few minutes later, I said: "In 1923, Weidenreich was spot on. It still took 30 years for the scientific community to accept he was right."

She ran off just to get away from me, then scuttled back under the tent with fogged glasses and face streaked with rain.

"Let me towel - "

She fled to the main tent to clean up.

I was alone only for minutes, but that was plenty of time to contaminate the Angel's strata with a 40-year-old American quarter, a gum wrapper and a paper clip.
Later, while an undergraduate was Sarah's 'political commissar', I heard a little shriek and knew my anachronisms had been found.

Every day, I waited for the chaos and recriminations of my senior year in high school when I suddenly became the son of a criminal. Nothing happened. Then Sir Keith and Mary Manon announced our 'Angel', and I pretended to smile for the scanners.

When we walked home under the stars, Andrei said: "You are very quiet, amigo."

"Sir Keith and M-Squared will get the glory. Book tours, honorary degrees. A life peerage. We're just shovel-guys."

"Eh. Not shovel-guy. You're one of the world's best bone-men." He smiled. "But you will get tenure. And I will do stratigraphy on Mars!”

I said angrily: "That's what this has all been about. Saving Mars! Diverting funds from history and archaeology and understanding ourselves to chasing phantasms on Pluto. And it's all a hoax."

Andrei frowned.

I shouted: "Sarah found contamination! Modern artefacts in the same layer as the Angel."

He waved his hand dismissively. "Every site is contaminated. Every dig team drops a penny in the dig, or a food wrapper. Every historical event has anomalies, spawning dozens of conspiracy theories. Mutually exclusive theories. "We talked to Sarah. Our mousy little friend was upset, but she wanted to believe. She did believe."

That night, I lay on the straw for hours. Andrei could jigger the soil analysis, but who had forged the six-winged skeleton? I had touched the curving wings; I knew my bones. Impossible to fake.

There was compelling evidence that the angel was a hoax. There was compelling evidence it was not. It was thus in all scientific revolutions, both true and failed. There was in each a time of wonder and confusion when logic was inadequate and only faith remained, dignified as intuition.

I walked restlessly until dawn and shouted at the stars: "Little angel, where are you from?"

What did I believe? And would I ever know?

John P. Boyd has published 16 previous stories; this is his second for Nature. He is professor of atmospheric and oceanic science at the University of Michigan. Join the discussion of Futures in Nature at http://tinyurl.com/kkh3kt 